\title{
Trademark Infringement by Domain Name Registrars
}

\begin{abstract}
Trademark Act, as amended in 2005, provides enforcement against intermediaries whose services are used by a third party (that is usually the infringer itself) for the infringement. In the HYUNDAI case the registrars of the domain names, trusted by the resellers of cars having formerly been members of the HYUNDAI commercial chain in Hungary, were sued together with the resellers for the reason that they did not cancel the registration of the domain names after the commercial chain had been ceased. The Hungarian courts of first and second instance built their judgements on the ECJ's BMW judgement (C-63/97). Emphasis is given also on a case relating to infringement by an operator of an Internet home page, as the latter was condemned by the Hungarian Court of first instance for not complying with the Act on Electronic Commerce. Nevertheless, the court of second instance condemned him not therefore but for the tort in respect of the provisions of the Civil Code, e.g. for injury of reputation. Finally, the article is closed by an outlook on ideas on the development of EC law relating to liability of intermediaries.
\end{abstract}

Keywords: trademarks, domain names, infringement, liability, intermediaries.

Infringement of a trademark is an unlawful conduct. As a result of globalisation of commerce today it is more widespread than it was fifty years ago. The most common form of infringement is affixing another's mark to goods or packaging without the consent of the trademark proprietor or using it in advertising.

A special kind of trademark infringement is the unlawful use of a mark in computers. The most spectacular cases of this kind are the recent GOOGLE judgements rendered by the $\mathrm{ECJ}^{1}$ and the French Supreme Court. ${ }^{2}$ In the latter kind of infringement there appears a further person on the side of the traditional infringers and advertisers: the intermediary service provider, who is often creator of the domain name.

\section{Legal framework in Hungary}

The Hungarian Trademark Act of 1997, as amended in 2005, provides in Sec. 27(4) that the claimant for infringement can apply for an injunction also against an intermediary whose services are used by a third party for infringement.

This provision is in conformity with Art. 8(3) of the Directive 2001/29/EC on the harmonisation of certain aspects of copyright and related rights in the information society. ${ }^{3}$ The Hungarian Act on Electronic Commerce and on Information Society of 2001 in Sec. 2 1) contains precise notions of different intermediaries, namely:

“l) 'Intermediary service provider' shall mean any provider of information society services:

1a) engaged in the transmission of information supplied by the recipient of the service through a telecommunications network, or who provides access to a telecommunications network (mere conduit and network access);

\footnotetext{
* LL.M., Professor of Law.

1 European Court of Justice C-236-238/08, 23 March 2010.

2 Cass. com. 13 July 2010.

3 OJ 2001 L 167.
} 
Ib) engaged in the transmission of information supplied by the recipient of the service in a telecommunications network, performed for the sole purpose of making more efficient the information's onward transmission to other recipients of the service upon their request (caching);

Ic) engaged in the storage of the information supplied by the recipient of the service (hosting);

Id) engaged in providing tools to the recipient of the service for the location of information (location tool services);",

In the Hungarian Act on Electronic Commerce there are further rules on liability of intermediaries, namely

(1) The intermediary service providers referred to as "mere conduit and network access" shall not be held liable for the information transmitted, on condition that the provider:

a) did not initiate the transmission;

b) did not select the receiver of the transmission; and

c) did not select or modify the information contained in the transmission.

(2) The acts of transmission and of provision of access referred to in Subsection (1) include the automatic, intermediate and transient storage of the information transmitted in so far as this takes place for the sole purpose of carrying out the transmission, and provided that the information is not stored for any period longer than is reasonably necessary for the transmission. (Sec. 8)

The intermediary service providers referred to as "caching" shall not be held liable for damages resulting from the automatic, intermediate and transient storage of the information transmitted on condition that:

a) the provider did not modify the information;

b) access to the stored information was provided in compliance with conditions on access to the information;

c) the provider complies with rules regarding the updating of the information, specified in a manner widely recognized and used by industry;

d) the intermediate storage did not interfere with the lawful use of technology, widely recognized and used by industry, to obtain data on the use of the information; and e) the provider acted expeditiously to remove or to disable access to the information it has stored upon obtaining actual knowledge of the fact that the information at the initial source of the transmission has been removed from the network, or access to it has been disabed, or that a court or any other authority has ordered such removal or disablement. (Sec. 9)

The intermediary service providers referred to as "hosting" shall not be held liable for the information stored at the request of a recipient of the service, on condition that:

a) the provider does not have actual knowledge of illegal activity in connection with the information and is not aware of facts or circumstances from which the illegal activity or information is apparent; or

b) the provider, upon obtaining knowledge or awareness of what is contained in Para.

a) acts expeditiously to remove or to disable access to the information. (Sec. 10) 
The intermediary service providers referred to as "location tool service" shall not be held liable for damages resulting from allowing access to the information according to Para. Id) of Sec. 2, on condition that:

o) the provider does not have actual knowledge of illegal activity in connection with the information and is not aware of facts or circumstances from which the illegal activity or information is apparent; or

b) the provider, upon obtaining knowledge or awareness of what is contained in Para.

o) acts expeditiously to remove or to disable access to the information. (Sec. 11)

The rules on mere conduit, catching, hosting correspond to those used in Art. 12-14 of the Directive 2000/31/EC on certain legal aspects of information society services, in particular electronic commerce in the Internal Market. ${ }^{4}$

\section{The HONDAI case}

Introducing the case history, I observe that the activity of the registrars were closely connected to that of the Hungarian car retailers. As a result I start to deal their conduct together, as the Court did, too.

1. The facts were not usual: earlier before the situation turned to infringement the retailers, the defendants had been regular commercial partners of the owner of the Hyundai marks. The claimant and defendant No. 1 concluded a Distributorship Agreement for Hungary on $1^{\text {st }}$ January 2001, with exclusivity, for a period of 2 years. Section 14 of the Distributorship Agreement provided in respect of the marks that "the distributor does neither acquire nor seek to acquire the trademarks, trade names for the goods relating to the Agreement; moreover, the distributor uses the marks only in selling these goods". Parallel with executing this contract, defendant No. 1 built up a commercial chain for Hyundai vehicles and the other defendants No. 2-No. 18 used the mark in publicity, commercial papers, correspondence, buildings, auto shops, service stations etc. Moreover, three further defendants let the domain names "hiundayauto.hu", "hyundai-speed.hu" and "hyundai-spur. hu" registered.

However, a few years later the situation changed: On $1^{\text {st }}$ November 2004, the EC regulation on the application of Art. 81(3) of the EC Treaty on categories of vertical agreements and concentrated practices in the motor vehicle sector No. 1400/2002/EC entered into force in Hungary. As a result, the claimant and the defendant agreed on the termination of the Distributorship Agreement. The claimant informed defendant No. 1 already in September 2004 that further deliveries within EC countries will be made to his German daughter company. However, as long as the latter has not established his service stations, i.e. until the end of January 2005 the claimant delivered motor vehicle parts and accessories to Hungary cooperating with his former partners.

After this period ended, the claimant invited the defendants No. 1-23 to stop the use of claimant's marks. As the defendants did not comply with this invitation, the claimant filed the suit for trademark infringement. 
2. In his judgement of $21^{\text {st }}$ November 2007, the Metropolitan Court ordered the defendants to discontinue the use of the HYUNDAI marks.

Hereafter stands only a summarized report on the grounds of the judgement in an extent which I believe is necessary for the understanding in respect of the three intermediaries, i.e. the registrars (defendants No. 19, 22, 23) whose activity was in my opinion only contributory. As the judgement states, it was not contested by the parties that at the beginning the defendants were not unfair by using the marks for selling Hyundai vehicles, making publicity.

But after the termination of their commercial relationship the situation changed, and the claimant alleged that the defendant could make publicity only insomuch that they did not give the impression of being members of the claimant's commercial chain. In this respect, the claimant referred to the ECJ's judgement (C63/97) rendered in the BMW case, which he believed to be applicable in this case, too. Moreover, he stressed that the publicity on the Internet does not allow the use of domain names with the word HYUNDAI.

The Court accepted this standpoint and quoted the EC1's BMW judgement as a test of the possibilities, and the borders of the rights of resellers being independent from the car producer. Namely,

"The proprietor of a trademark is not entitled to prohibit a third party from using the mark for the purpose of informing the public that he carries out the repair and maintenance of goods covered by that mark and put on the market under that mark by the proprietor or with his consent or that he has specialised or is a specialist in the sale or the repair and maintenance of such goods, unless the mark is used in a way that may create to the impression that there is a commercial connection between the other undertaking and the trademark proprietor, and in particular that the reseller's business is affliated to the trade mark proprietor's distribution network or that there is a special relationship between the two undertakings. "5

The Metropolitan Court added to this quotation that without the use of the HYUNDAI sign the reseller could not inform the public that he was specialised or was a specialist in the sale of such vehicles. As a result, the sign in question has an informative character and its use is necessary as a guarantee of the rights of the reseller who does not acquire unfair advantage from the distinctive character or reputation of the mark. Thereafter, the Metropolitan Court examined whether defendant No. 1 used the marks in question in a form which could make the impression to the public that he belonged to the official chain of the claimant. The Court held in this respect that, e.g. the use of the marks as a domain name surpassed the reasonable degree. It cannot be accepted that this form of use was necessary. Moreover, use of the trade name was also an infringement. Furthermore, as the defendants were earlier members of the commercial chain and rendered services within this, this fact has to be considered as well. Under such circumstances the requirement of good faith must also be complied. As a result, these facts are speaking against the defendants.

3. Against the judgement of the Metropolitan Court, the defendants-except one of them-filed an appeal, including the registrars, too. The Metropolitan Court of Appeal made its judgement on $17^{\text {th }}$ March 2009 and dismissed the appeals reducing the procedural fees.

5 Para. 64. and operative part of the ECJ's judgement. 
It is worthwhile to report that the Court of Appeal, appreciating the "detailed reference" to the ECJ's BMW judgement. It stated that in the suit, only the conclusions of the BMW judgement served as directives, since the use of the marks by the defendants was suitable for making the public suppose that there was a special tie with the owner of the mark. The court of first instance, appreciating the considerations of the BMW judgement disclosed and qualified the acts of use of the defendants correctly one by one in details, considering whether they correspond to the right on notice of information or exceed the frames of this right. An example of the detailed and convincing reasons of the judgement of the court of first instance is e.g. the appreciation of the use of the HYUNDAI marks by defendant No. 8 . informing the public on sale of Hyundai cars alongside with others objected in the judgement.

Relating to the registrars, i.e. defendants No. 19, 22, 23 the Court of Appeal says only that they repeated their statement on good faith and told that they would comply with the judgement. By the way their appeal was filed only against the procedural fees. In this respect the Court of Appeal said that a complete dispensation with the procedural fees had not been possible considering the rule of Sec. 80(1) of the Code of Civil Procedure. Namely, it could not be established that they had not given any cause for the procedure, moreover they had not acknowledged the claim with the first trial (8. Pf.20.533/2008).

4. The majority of the defendants requested the revision at the Supreme Court. The Supreme Court rejected the revision requests including also those filed by the registrars (Pf. IV.20.796/2009).

\section{Comments}

a) Applying the ECJ's BMW judgement as a leading case was not only suitable a but also convincing. It is not surprising that the parties requested this, too. From time to time the ECJ comes back to the same as well, this was the case, e.g. in the OPEL (C-48/05) ${ }^{6}$ judgement, or in the GILLETTE (C-228/03) ${ }^{7}$ one. It can be reported that the Hungarian Courts follow ECJ's teaching, too, including reference cases in trademark law. ${ }^{8}$

${ }^{6}$ It is true that BMW concerned the use of a sign identical to the trade mark for services which were not identical to those for which that trade mark was registered, since the BMW trade mark, at issue in the main proceedings, was registered for vehicles but not for vehicle repair services. However, the vehicles marketed under the BMW trade mark by the proprietor of that mark constituted the subject-matter of the services-the repairing of vehicles-supplied by the third party, so that it was essential to identify the origin of the BMW cars, he subject-matter of those services. It was having regard to that specific and dissociate link between the products bearing the trade mark and the services provided by the third party that the Court of Justice held that in the specific circumstances of the BMW case, use by the third party of the sign identical to the trade mark in respect of goods marketed not by the third party but by the holder of the trade mark fell within Art. 5(1) of the directive (Para. 27).

7 The use of the trade mark will not comply with honest practices in industrial or commercial matters where, first, it is not done in such a manner that it may give the impression that there is a commercial connection between the reseller ad the trademark proprietor (BMW, Paras 51-42 of this judgement).

8 Cf. Vida, S.: The impact of the judgements of the ECJ on the Hungarian trademark law. AIPPI Proceedings (Hungary). 2010, 53. 
b) The defence of the registrars (in the appeal proceeding) was limited to lack of confusion of the domain names composed of the mark HYUNDAI. It is obvious that this was a weak defence. Reference to good faith was also unsuccessful as trademark infringement is judged in consideration of objective criteria. It is not surprising that they were condemned by the three jurisdictions. The Court of Appeal, in stating the infringement, applied the rules of the Act on Electronic Commerce with tacit analogy saying that "they did not acknowledge the claim with the first trial". Moreover, in the term of the Act of Electronic Commerce this would not have been sufficient.

c) Neither the Metropolitan Court, nor the Metropolitan Court of Appeal applied Sec. 27(4) of the Trademark Act in respect of the registrars. I believe the ground for this was that the claim was filed against a joinder of parties. If the claim had been filed separately against the registrars they would have been condemned probably with references to Sec. 27(4) of the Trademark Act.

d) In respect of judging the infringing use of other's marks as domain names, it was probably a relief that relating to this subject there were some precedents at disposal. ${ }^{9}$ The judicial practice in this respect corresponds to that of other Member States of the EU. ${ }^{10}$

\section{Excursion: Infringement by an operator of an internet home page}

Both regarding the facts and the enforcement, some similar questions were to be judged in a procedure against the operator of the Internet home page "www.fusz.hu", though in this case the claim was not in connection with trademark infringement. A reader's letter was published on the internet home page of the defendant, offending the honour and reputation of the claimant. It is a fact that after a registration everybody was free to put there, according to taste, any tests, comments or reader's letters. Though the County Court of SzabolcsSzatmár-Bereg stated that the defendant is a hosting service provider and in conformity with Sec. 2(1) c) of the Act on Electronic Commerce he is exempted from liability supposing that upon obtaining awareness of the illegality of the text displayed on his home page he acts immediately to remove it. This ought to be made on receipt of the claim at the latest. Omitting this, he became guilty in respect of injuring Sec. 75(1), 76 and 78(1) of the Civil Code. As a result, the Court obliged him to remove the contested reader's letter and to pay damages (2.P. 20.307/2008).

\section{Comments}

a) The facts in respect of liability of an internet home page operator, in respect of injury of reputation, even if the latter relates to a private person, is a typical element which appears in trademark infringement cases, too. Even if we do not think only to "great" or "famous" trademarks but to marks that are at the beginning of getting acquainted it is obvious that even owners of such marks are careful about the reputation of their marks. The loss of

9 Supreme Court, see BH 2005.145; see also Bacher, G.: Összefoglaló a doménnév regisztrációról és a doménnevekkel összefüggő jogérvényesítésről tartott kerekasztal-beszélgetésről (Summary on the round-table on due process in connection with domain names and domain registration). Iparjogvédelmi és Szerzői Jogi Szemle, 112 (2007) 1, Különszám, 78.

10 For German Court decisions see Ingerl, R.-Rohnke, Ch.: Markengesetz. 3rd ed., München, 2010, after Para. 15 Rn. 167. For British ones see Morcom, R.-Roughton, A.-Malyncz, S.: The Modern Law of Trade Marks. 3rd ed., London, 2008, 17.18-17.25. 
reputation, moreover, bad reputation has an unfavourable effect in business, furthermore, often in respect of legal protection.

b) In the present case the Internet home page was not operated in the frame of business life. Though even if the operator was not aware of the injurious character of the reader's letter (I have serious doubts in this respect), as a result of the requirements of good faith and fairness he should have removed the contested reader's letter immediately after receipt of the claim (there was no warning letter in the case). As he did not do this and he acted only after being condemned by the court this omission was an obvious negligence, even if the Act on Electronic Commerce was not applicable in the case.

c) In respect of enforcement there is a further parallelism between the judgement rendered in the HYUNDAI case and that relating to the Internet home page (www.fusz.hu). In neither of them were the final judgements rendered with reference to the Act on Electronic Commerce. Moreover, exemption of liability, even applying the provisions of the said Act by analogy, would not have been stated by the courts.

\section{Outlook: Intermediaries in the EC law}

As told at the beginning, the above referred Hungarian provisions follow those of the European Union. It is not surprising that in the judicial practice of other Member States of the EU more complicated questions arise in this respect. As a result the International Association for Competition Law (LIDC) put the study of liability of intermediaries ${ }^{11}$ on the agenda of its Oxford Congress of 2011. The Hungarian Group of this Association prepared a respectable ${ }^{12}$ report to the exhaustive Questionnaire. From the final recommendations of the Hungarian Groups, I refer only to some, namely,

- the rules on infringement of the intellectual property as stipulated in the Enforcement Directive of the $\mathrm{EC}^{13}$ (Art. 9.1.a) shall be applied in case of an unfair competition as well,

- liability in respect of mere conduit should be applied similarly to hosting,

- caching and search engine providers, impeding the accessibility of websites and docking domain names can be specific forms of injunctions, etc.

I look forward to learn what kind of other propositions will be made in respect of this brand-new subject.

11 To what extent should on-line intermediaries (such as ISPS and operators of offline market place) be responsible for the control or prohibition of unfair competitive practices (in particular sales of products contrary to the law) carried out on their systems?

$129^{\text {th }}$ May 2011, Hungarian National Rapporteur: Adam Liber.

13 OJ 2004 L 157. 